\title{
Control of crystallization and caking of skim milk powder in fluidized beds: A preliminary study
}

\author{
Zhe Liang, Tim LANGRISH* \\ School of Chemical and Biomolecular Engineering, Building J01, The University of Sydney, \\ NSW 2006, Australia
}

\begin{abstract}
Received 2nd July 2009 - Revised 12 January 2010 - Accepted 22 January 2010
Published online 18 March 2010
\end{abstract}

\begin{abstract}
A stirred fluidized bed has been used with the aim of crystallizing skim milk powder from spray drying without caking the powders. The skim milk powder was crystallized in a stirred fluidized bed, then a sorption box was used to characterize the stability and a standard flow tester for dairy powders was used to measure the flowability. The results showed that the samples from the fluidized bed did not adsorb as much water as the original samples, suggesting that the samples from the fluidized bed were more stable than the original samples. The results of the flowability tests showed that the samples from the stirred fluidized beds were significantly more free flowing than either the caked samples from the sorption box or the original samples. This preliminary study indicates that fluidized-bed processing is a promising method for crystallizing some dairy powders.
\end{abstract}

lactose / crystallization / fluidization / sorption / flowability / dairy powder

\begin{abstract}
摘要 - 控制脱脂乳粉在流化床上结晶和结块的初步研究。未结块的喷雾干燥脱脂粉经摚拌 流化床法生产结晶脱脂粉。脱脂粉在摚拌流化床中结晶, 然后用一个吸收盒来表征脱脂粉的 稳定性, 以及采用标准的乳粉流动实验来测定乳粉的流动性。实验结果表明, 搅拌流化床法 生产乳粉的吸水性低于原始乳粉样品的吸收性, 即该乳粉的稳定性优于原始样品。乳粉流动 实验结果表明搅拌流化床法生产的乳粉流动性显著地优于原始样品和结块的乳粉样品。初步 研究结果说明了搅拌流化床是一种有潜力的生产结晶乳粉的方法。
\end{abstract}

\section{乳糖 / 结晶化 / 流化 / 吸附作用 / 流动性 / 乳粉}

Résumé - Contrôle de la cristallisation et du mottage d'une poudre de lait écrémé en lits fluidisés. Étude préliminaire. Un lit fluidisé agité mécaniquement a été utilisé dans le but d'obtenir la cristallisation d'une poudre de lait écrémé après séchage par atomisation et d'éviter la prise en motte de la poudre. Après cristallisation de la poudre de lait écrémé en lit fluidisé agité, une boîte de sorption a été utilisée pour caractériser sa stabilité et l'écoulement a été mesuré dans un testeur classique pour les poudres laitières. Les résultats ont montré que les échantillons obtenus après passage sur lit fluidisé n'absorbaient pas autant d'eau que les échantillons originels, ce qui suggère une plus grande stabilité des échantillons obtenus par lit fluidisé. Les tests d'écoulement ont montré que les échantillons obtenus après passage sur lit fluidisé étaient significativement plus libres d'écoulement que les échantillons pris en motte de la boîte de sorption ou que les échantillons originels. Cette étude préliminaire indique que le traitement par lit fluidisé est une méthode prometteuse pour réaliser la cristallisation de certaines poudres laitières.

lactose / cristallisation / fluidisation / sorption / écoulement / poudre laitière

*Corresponding author (通讯作者): t.langrish@usyd.edu.au 


\section{INTRODUCTION}

New engineered powders in industries producing consumer, pharmaceutical, and food materials often face challenges due to powder stickiness, which may affect the flowability and the stability of the powders. Powder flowability is important in handling and processing operations $[3,5,6,11]$. Flow problems in hoppers and silos are commonplace problems for engineers and process operatives [10]. It has been well known that the stickiness and amorphous nature of the material depend on the glasstransition temperature of the material and the environmental conditions. When an amorphous component is exposed to particular conditions of temperature and humidity, the molecules in amorphous solids can mobilize and crystallize. The crystallization process leads to water being expelled from the solid desorption, since the crystalline form of the solid is more compact than the amorphous form. The expulsion of water leads to liquid bridges, which are formed between powder particles. These bridges can make the particles cohere to each other, and the solidification of liquid bridges leads to powder caking [14], which then accompanies the crystallization process. Reducing stickiness in materials may be achieved through partial or complete crystallization of the sticky amorphous components, which may reduce the caking that is associated with crystallization.

Crystallization can be carried out on belts (the Niro Tixotherm ${ }^{\mathrm{TM}}$ process and the APV Paradry ${ }^{\mathrm{TM}}$ process [12]). Fluidized-bed processing offers the advantage that fluidized beds are already present at the end of (or integrated with) spray dryers in dairy processing to do further drying. It is possible, with the approach proposed here, to operate them to do further crystallization and hence stabilization of the final powders.

Factors that are related to the crystallization process include, as reviewed above, temperature and humidity. This project investigates a potential method for crystallizing materials after spray drying without caking them, using a stirred fluidized bed to crystallize powders while agitating them to reduce the formation of liquid and solid bridges. The temperature and the humidity were controlled in the fluidized bed, in order to crystallize skim milk powder. After skim milk powder was treated in a fluidized bed, sorption behaviour and flowability were tested. Then the stability and the flowability of the powder were compared with those of the skim milk powder that was crystallized and caked in a static controlled temperature and humidity air environment.

\section{MATERIALS AND METHODS}

Skim milk powder (Coles, Australia), which was a spray-dried material, was used in this project. This powder had a moisture content of $4.6 \%$ (dry basis), as received. This material was used because it showed the moisture caking instability that was characteristic of amorphous powders, in that the material formed a solid cake after $\sim 24 \mathrm{~h}$ in an ambient environment of $23 \pm 3{ }^{\circ} \mathrm{C}$ and a relative humidity of $60 \pm 10 \%$. The material was therefore representative of an amorphous lactosecontaining powder that could be stabilized by processing it in a fluidized bed.

The powder was crystallized in a stirred fluidized bed, and the air in the fluidized bed was kept at controlled temperature and humidity. A diaphragm pump (Type: N022Sve, $220 \mathrm{~V}, 50 \mathrm{~Hz}, 0.08 \mathrm{~kW}$, Dwyer Instruments Inc., USA) was used to move air into the fluidized bed and through the powder. Before the air was pumped into the fluidized bed, the temperature of the air was controlled by a water bath, which was kept at $25^{\circ} \mathrm{C}$, and the humidity was controlled by bubbling the air through a bottle, which contained a saturated $\mathrm{NaCl}$ solution or a saturated $\mathrm{CaCl}_{2}$ solution to get different air humidities $(70-75 \%$ relative 


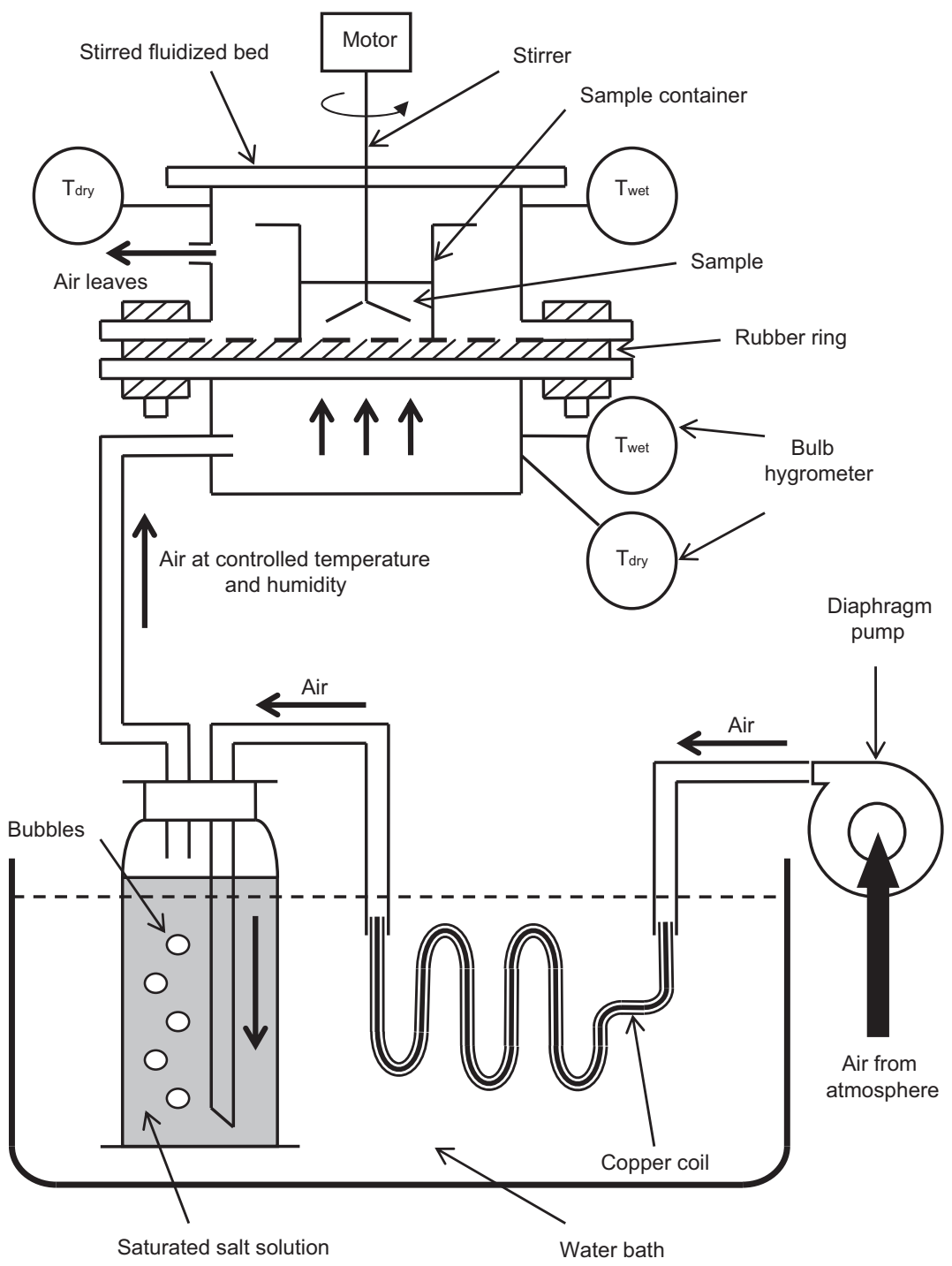

Figure 1. A line diagram of the apparatus for using a stirred fluidized bed to treat skim milk powder.

humidity for $\mathrm{NaCl}$ solution and $30-35 \%$ relative humidity for $\mathrm{CaCl}_{2}$ solution) $[8,15]$.

The line diagram in Figure 1 shows the apparatus that was used to treat skim milk powder. The skim milk powder was placed into the fluidized bed in a section of
$100 \mathrm{~mm}$ diameter, and then the stirrer and the pump were switched on. The flow rate of air was around $20 \mathrm{~L} \cdot \mathrm{min}^{-1}$. The rotational speed of the stirrer was kept at $34.5 \mathrm{rpm}$. The temperature was measured with a wet- and dry-bulb hygrometer, 


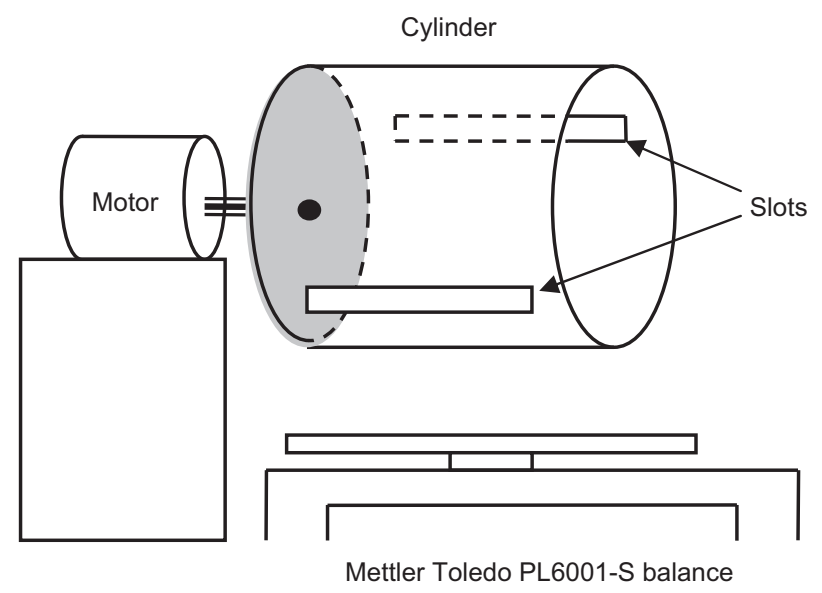

Figure 2. A diagram of the flowability tester used.

and the dry-bulb temperature in the fluidized bed was kept at $23 \pm 0.5{ }^{\circ} \mathrm{C}$. Two sets of experiments were designed to treat the powder over different time periods. In one set of experiments, the system was kept running for $6 \mathrm{~h}$, while in the other set of experiments, the system was kept running for $22 \mathrm{~h}$. The samples were then collected for further measurement and characterization.

\subsection{Characterization of products}

Moisture contents were determined using a gravimetric measurement method with a fan-forced drying oven (Thermoline TD$150 \mathrm{~F}$, Sydney, Australia) over a period of $24 \mathrm{~h}$ at temperatures of $85-100{ }^{\circ} \mathrm{C}$. Measurements of the sample weights were taken using a Mettler Toledo AB204-S analytical balance. The samples were left inside a sealed desiccating container with a relative humidity of $73 \%$ and $25{ }^{\circ} \mathrm{C}$, which is called a sorption box. Then the samples were monitored for moisture change as a function of time, indicated by weight gain and loss. The reasons for the weight gain and loss of the powder were that the spray-drying process produced amorphous particles, such as skim milk powder, and they tend to crystallize [4, 5]. Amorphous components are thermodynamically unstable and tend to crystallize, and the presence of sufficient moisture allows them to move and hence crystallize, giving a more compact solid than the amorphous form. In the crystallization process, water is being expelled from the solids [1]. Lehto et al. [9] suggest that the amount of water expelled during crystallization is an indication of the degree of crystallinity and stability of the solids.

Three powder treatments were tested by a standard flowability tester for dairy powders [13]. The three kinds of skim milk powder were (a) the powder that was treated in the fluidized bed, (b) the powder that was crystallized and caked in the sorption box, and (c) the original powder. The results of the flowability test were indicated by the percentage masses flowing out of a flowability tester as a function of time. The flowability tester was a cylinder that was rotated by a small electric motor. The inside diameter of the cylinder was $120 \mathrm{~mm}$ and its length was $100 \mathrm{~mm}$. There were two slots that were located opposite to one another in the wall of the cylinder for the material to flow out. The flowability tester is 


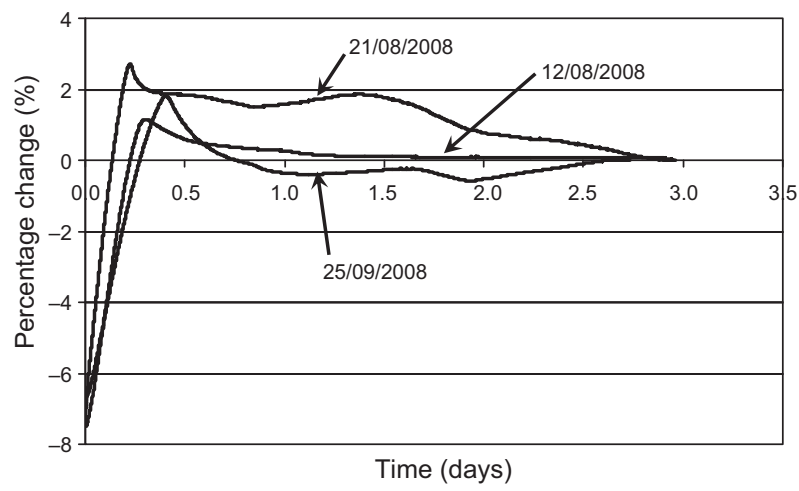

Figure 3. The sorption behaviour of the original samples in the sorption box, $70-75 \%$ relative humidity ( $\mathrm{NaCl}$ solution), $25{ }^{\circ} \mathrm{C}$.

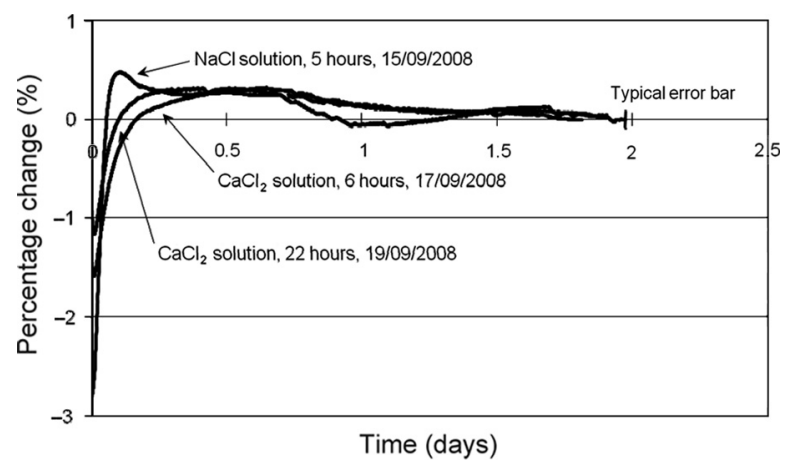

Figure 4. The sorption behaviour of the samples treated in the fluidized bed, then characterized in the sorption box, $30-35 \%\left(\mathrm{CaCl}_{2}\right.$ solution) or $70-75 \%$ relative humidity $(\mathrm{NaCl}$ solution $), 25{ }^{\circ} \mathrm{C}$.

sketched in Figure 2. The size of the two slots was $70 \mathrm{~mm} \times 4 \mathrm{~mm}$, and the rotational speed of the cylinder was $34.5 \mathrm{rpm}$. The masses of the powder flowing out of the tester were measured using a Mettler Toledo PL6001-S balance ( $\pm 0.1 \mathrm{~g})$.

\section{RESULTS AND DISCUSSION}

\subsection{Sorption tests}

From the sorption box tests (as described in Chiou et al. [2]), the data collected for the mass change as a function of time were converted into moisture content changes and plotted. Figures 3 and 4 show the characteristic behaviour of amorphous samples, in that the process of crystallization involves the initial adsorption of water [9], followed by desorption as crystallization occurs. The final moisture content can be greater than the initial moisture content if there is moisture trapped in the final crystalline structure. All the percentage moisture changes are in terms of the mass of moisture divided by the dry mass of material, multiplied by 100 to give percentages. 
Table I. Results of the flowability tests.

\begin{tabular}{|c|c|c|c|c|c|c|c|c|c|}
\hline & \multicolumn{3}{|c|}{ First experiment } & \multicolumn{3}{|c|}{ Second experiment } & \multicolumn{3}{|c|}{ Third experiment } \\
\hline & $\begin{array}{c}\text { Total } \\
\text { mass }(\mathrm{g})\end{array}$ & $\begin{array}{c}\text { Mass out } \\
(\% \text { emerging })\end{array}$ & $\begin{array}{c}t \\
(\mathrm{~s}) \\
\end{array}$ & $\begin{array}{c}\text { Total } \\
\text { mass }(\mathrm{g})\end{array}$ & $\begin{array}{c}\text { Mass out } \\
\text { (\% emerging) }\end{array}$ & $\begin{array}{c}t \\
(\mathrm{~s}) \\
\end{array}$ & $\begin{array}{c}\text { Total } \\
\text { mass }(\mathrm{g})\end{array}$ & $\begin{array}{c}\text { Mass out } \\
(\% \text { emerging })\end{array}$ & $\begin{array}{c}t \\
(\mathrm{~s}) \\
\end{array}$ \\
\hline Original sample & 2.0 & $1.4(70 \%)$ & 30 & 1.8 & $1.3(72 \%)$ & 33 & 1.8 & $1.0(55 \%)$ & 34 \\
\hline $\begin{array}{l}\text { Caked sample from } \\
\text { sorption box }\end{array}$ & 4.7 & $2.4(51 \%)$ & 62 & 4.1 & $1.8(44 \%)$ & 45 & 4.2 & $1.7(41 \%)$ & 36 \\
\hline Fluidized bed $6 \mathrm{~h}$ & 1.8 & $1.8(100 \%)$ & 24 & 1.7 & $1.7(100 \%)$ & 29 & 1.8 & $1.7(94 \%)$ & 29 \\
\hline Fluidized bed $22 \mathrm{~h}$ & 1.7 & $1.5(88 \%)$ & 17 & 1.7 & $1.5(88 \%)$ & 19 & 1.6 & $1.5(94 \%)$ & 20 \\
\hline
\end{tabular}

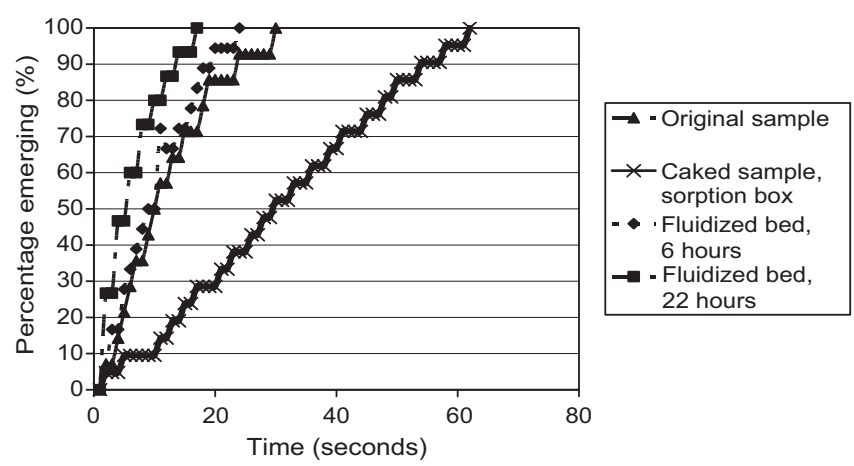

Figure 5. The percentage of the powder emerging from the flowability tester as a function of time.

Figure 3 shows an overall gain of $6-8 \%$ in moisture content, initially $8-10 \%$ before crystallization, in the mass of the untreated sample. Again, as shown in Figure 4, the overall mass gain is about $3 \%$ and $3.5 \%$ before crystallization of the skim milk powder exhibiting sorption behaviour which was treated in a fluidized bed with different solutions controlling the relative humidity. The samples treated in the fluidized bed did not adsorb as much water as the original samples, showing that the samples from the fluidized bed are more stable than the original samples [9]. A typical error bar is included in Figure 4 to show the magnitude of the uncertainty in the moisture content change. The uncertainty in the time was smaller than the line thicknesses in these figures. The percentage changes in moisture content are relative to the final moisture contents in the samples.

\subsection{Flowability tests}

Table I shows the flowability of the different samples that were produced. Three repeat experiments were carried out, shown in each section to show the repeatability of the treatment and the testing. The total mass is the amount of sample that was put in the flowability tester. The mass out is the mass that came out from the flowability tester, and the percentage is the percentage of the total mass that emerged. Only between $41 \%$ and $51 \%$ of the inserted sample came out of the tester for the heavily caked sample from the sorption box (with the original sample), because the sample was so 

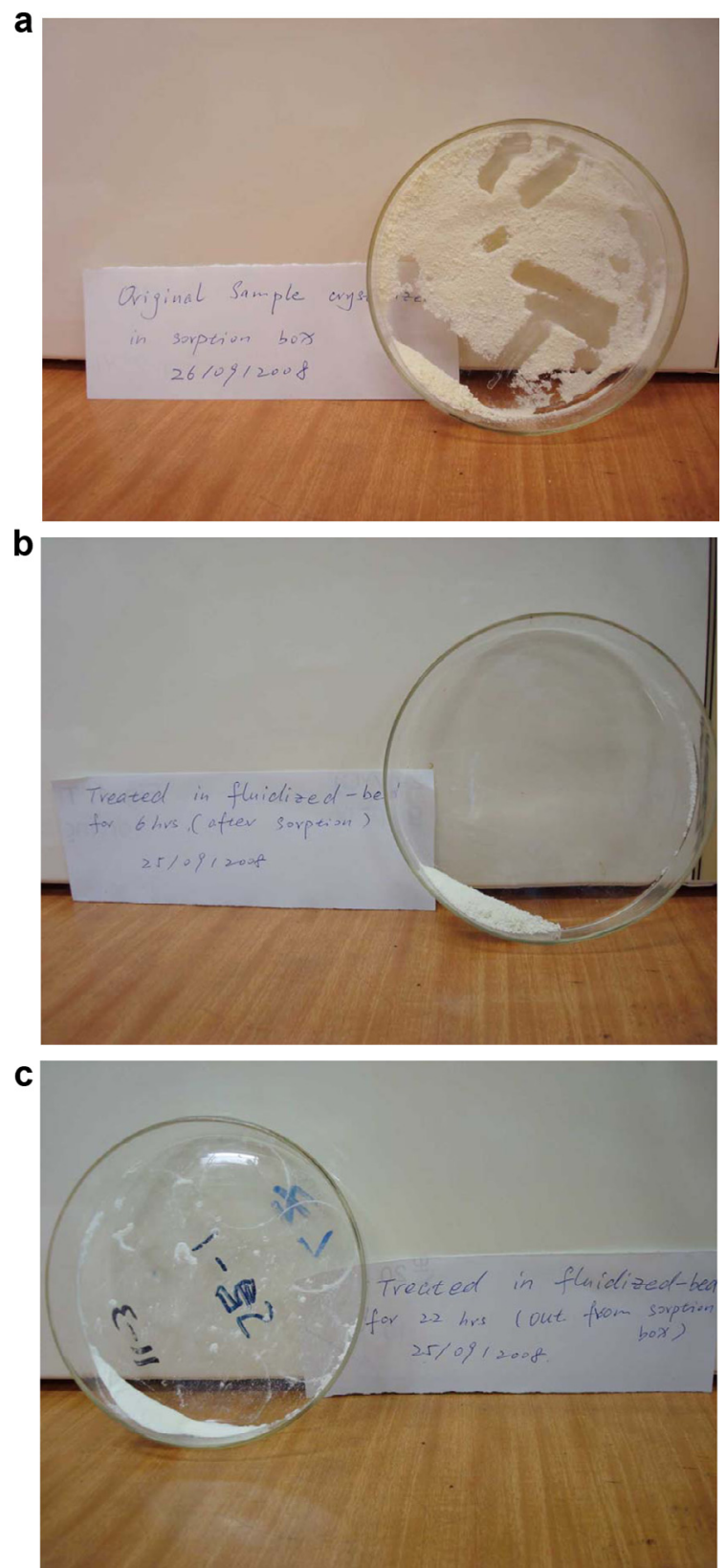

Figure 6. Photograph of the samples (a) after static crystallization in the sorption box, (b) after 6-h treatment in the fluidized bed without static crystallization in the sorption box and (c) after 22-h treatment in the fluidized bed without static crystallization in the sorption box. 
heavily caked. The time is the total time that was taken for the amount of sample that actually emerged to flow out of the tester. Figure 5 shows the percentage of the powder that emerged from the tester as a function of time from the first experiment with each treatment. It is clear that the caked sample from the sorption box (70-75\% relative humidity, $25{ }^{\circ} \mathrm{C}$ ) is significantly less free flowing than the same original sample, but that the samples from the fluidized beds are significantly more free flowing than either the caked samples from the sorption box or the original samples.

Photographs of the samples that were allowed to crystallize by water sorption in the sorption box (Fig. 6a) show that they were heavily caked and hence had poor flowability. The samples treated in the fluidized bed for 6 h (Fig. 6b) and 22 h (Fig. 6c) showed much greater visible flowability, in agreement with the results from the flowability tester shown in Figure 5. While the processing times reported here are long relative to the times typically employed in fluidized-bed drying (5-30 $\mathrm{min})$, there is considerable future work to be done on which dairy products are most suitable for this processing and how to operate the fluidized beds to best do this processing. These preliminary results should not be seen as dismissing the potential to process some dairy products in this way.

\section{CONCLUSIONS}

These results show that the samples that were treated in the stirred fluidized bed were more free flowing and more stable with respect to (less) moisture adsorption than the untreated samples. Future work may include the use of higher temperatures in the fluidized bed, at similar relative humidities, in order to treat the samples more quickly [7]. Such work may necessitate redesign of the stirrer inside the fluidized bed. The aim of the redesign is to make the rotational speed of the stirrer faster, and the effect of the shape and the position of the stirrer will be studied [8].

\section{REFERENCES}

[1] Aguilera J.M., del Valle J.M., Karel M., Caking phenomena in amorphous food powders, Trends Food Sci. Technol. 6 (1995) 149-155.

[2] Chiou D., Langrish T.A.G., Braham R., Partial crystallization behavior during spray drying: simulations and experiments, Dry. Technol. 26 (2008) 27-38.

[3] de Silva S.R., Characterisation of particulate materials - a challenge for the bulk solids fraternity, Powder Handl. Process. 12 (2000) 355-362.

[4] Fitzpatrick J.J., Barry K., Cerqueira P.S.M., Iqbal T., O'Neill J., Roos Y.H., Effect of composition and storage conditions on the flowability of dairy powders, Int. Dairy J. 17 (2007) 383-392.

[5] Fitzpatrick J.J., Hodnett M., Twomey M., Cerqueira P.S.M., O'Flynn J., Roos Y.H., Glass transition and the flowability and caking of powders containing amorphous lactose, Powder Technol. 178 (2007) 119-128.

[6] Knowlton T.M., Carson J.W., Klinzing G.E., Yang W.C., The importance of storage, transfer and collection, Chem. Eng. Progr. 90 (1994) 44-54.

[7] Kuipers N.J.M., Stamhuis E.J., Beenackers A.A.C.M., Fluidization of potato starch in a stirred vibrating fluidized bed, Chem. Eng. Sci. 51 (1996) 2727-2732.

[8] Langrish T.A.G., Assessing the rate of solidphase crystallization for lactose: the effect of the difference between material and glasstransition temperatures, Food Res. Int. 41 (2008) 630-636.

[9] Lehto V.-P., Tenho M., Vaha-Heikkila K., Harjunen P., Paallysaho M., Valisaari J., Niemela P., Jarvinen K., The comparison of seven different methods to quantify the amorphous content of spray dried lactose, Powder Technol. 167 (2006) 85-93. 
[10] McGee E., Go with the flow, Chem. Eng. 755 (2004) 40-41.

[11] Ortega-Rivas E., Review and research trends in food powder processing, Powder Handl. Process. 14 (2003) 18-25.

[12] Peters R., Economic aspects of cheese making as influenced by whey processing options, Int. Dairy J. 15 (2005) 537-545.

[13] Pisecky J., Handbook of Milk Powder Manufacture, Niro A/S, Copenhagen, Denmark, 1997.
[14] Roos Y.H., Importance of glass transition and water activity to spray drying and stability of dairy powders, Lait 82 (2002) 475-484

[15] Vertucci C.W., Roos E.E., Crane J., Theoretical basis of protocols for seed storage. 3. Optimum moisture contents for pea-seeds stored at different temperatures, Ann. Bot. 74 (1994) 531-540. 